\title{
Réflexions sur les ambiguïtés de la notion d'outil. Transformation de l'outil au cours de l'évolution
}

Jean-Michel Dutuit et Pierre Dutuit

\section{(2) OpenEdition}

\section{Journals}

Édition électronique

URL : https://journals.openedition.org/tc/559

DOI : $10.4000 /$ tc.559

ISSN : 1952-420X

Éditeur

Éditions de l'EHESS

\section{Édition imprimée}

Date de publication : 1 novembre 1995

ISSN : 0248-6016

\section{Référence électronique}

Jean-Michel Dutuit et Pierre Dutuit, « Réflexions sur les ambiguïtés de la notion d'outil. Transformation de l'outil au cours de l'évolution », Techniques \& Culture [En ligne], 23-24 | 1995, mis en ligne le 07 décembre 2005, consulté le 29 septembre 2022. URL : http://journals.openedition.org/tc/559; DOI : https://doi.org/10.4000/tc.559

Ce document a été généré automatiquement le 29 septembre 2022.

Tous droits réservés 


\section{Réflexions sur les ambiguités de la notion d'outil. Transformation de l'outil au cours de l'évolution}

Jean-Michel Dutuit et Pierre Dutuit 